\title{
Understanding the Asia-Pacific
}

Tom Conley

Griffith University

Michael K. Connors, Remy Davison and Jorn Dosch, The New Global Politics of the Asia Pacific (London and New York: RoutledgeCurzon, 2004), x 240 pp., £20.99, ISBN 0415285631

Gloria Davies and Chris Nyland (eds), Globalisation in the Asian Region: Impacts and Consequences (Cheltenham: Edward Elgar, 2004), xiii 256 pp., \$64.95, ISBN 1843766272

Both of these books make a valuable contribution to understanding the Asia-Pacific, albeit from different perspectives. The first is a multi-authored textbook-style treatment of the international politics of the Asia-Pacific region, and would provide an excellent resource for undergraduates, perhaps at upper-year level. It will also be invaluable for higher-level students wanting some background on the region and for those just generally interested in current affairs. The second book under review here is a lessstructured effort and the quality of the offerings is more uneven, which is understandable for an edited volume. No doubt, however, teachers will be able to utilise various chapters for teaching courses on East Asia.

The authors of The New Global Politics of the Asia Pacific divide the book into two sections: the first covers what they call traditional 'state-centric concerns' ( $p$. ix) and the second deals with 'new agenda issues', which, they argue, 'balances the state centric biases of the first section of the book' (p. ix). The book is not an edited volume, but each chapter, contrary to usual practice for many textbooks, is individually attributed. No chapters are written jointly, not even the introduction. 
The book's major beneficial feature for me was its attempt to understand the various topics covered through the major theoretical paradigms in international relations. The theoretical approaches included are realism and neo-realism, inter-dependence, neoliberal institutionalism, neo-Marxism and constructivism. Although the latter is increasingly important, many international relations textbooks treat it as an afterthought to the traditional tripartite schema or not at all. However, the brief coverage of the various theoretical approaches in the introduction (six pages) could have been more extensive, given the author's contention that: 'we have attempted to write a book that is useful for those new to the study of Asia-Pacific international politics, and for those relatively new to international relations theory' ( $p$. ix). To gain much from the theoretical explications at the end of each chapter, readers would need to have a reasonably sound understanding of the theoretical frameworks already. This is not necessarily a big problem for the book, as it is primarily an introduction to the Asia-Pacific and not to IR theory! Some chapters' theoretical analyses are a little tacked on and sparing in their attempt to integrate theory and empirical analysis. Even in these cases, however, the chapters at least provide a theoretical point of departure for more serious students.

The first part of the book deals with the relationship of particular countries-the United States, Japan, China and Australia-and regions-Southeast Asia and the European Union-with East Asia. The second half includes chapters on regional security, globalisation and regionalism, the Asian economic 'miracle' and the 'crisis', transnational actors, and culture and politics. The major omission in terms of subject matter is a background 'history chapter' that may have covered the inter- national 
politics of the region as a whole over the past several hundred years. Students attempting to come to grips with the international politics (and political economy) of the Asia-Pacific are always aided by an understanding of the past.

The chapters on the United States, Japan and China all include brief analyses of historical developments and then consider these three pivotal countries in terms of their relationships with each other and the region. This focus is appropriate given that the future trajectory of the region will, to a significant extent, be shaped by these three powers and their interactions. While they are very well written and have useful introductions, it is these chapters that would have benefited from more extensive theory sections.

The chapter on ASEAN is particularly good and is well matched by the one on globalisation and regionalism. Regionalism and regionalisation are increasingly important in the Asia-Pacific. This chapter is also very effective in integrating theory into its analysis. Connors takes a balanced view of Australia's role and position in the Asia-Pacific and concludes that:

Historically, Australia has not so much been a pawn of its great and powerful friends, but rather an active participant in the various economic and security mechanisms through which it pursues its national interests. ( $p$. 101)

The chapter on regional security covers the major flashpoints in the region and then deals with conflict and conflict avoidance. It also provides an outlook for the region based on neo-realist and liberal institutionalist scenarios. In my experience, this is the sort of conjecture that encourages student thinking and debate, but to which academics are often afraid of committing (apart from the entrepreneurs who generally 
over-simplify matters, deal in black and white, or place the 'End of' in their titles).

Connor's chapter on 'The Asian Economic Miracle and its Unmaking' will also provide a good starting point for students attempting to understand the truly amazing story of Asia's economic ascendancy. It provides an extensive section on differing approaches to political economy-liberal, realist and radical-before describing the crisis and its various explanations. The chapter on transnational actors covers the role of nongovernment organisations (NGOs) and multinational corporations (MNCs) and seeks to understand their influence through 'the "strong state" versus "weak state" conundrum' (pp. 183-4).

The final chapter, 'Culture and Politics in the Asia-Pacific', is an effective point of departure for the text. It covers the Asian values debate and the role of ideas about human rights in the region. In an era when human rights seem to have been subsumed by concerns about terrorism and engulfed by the desire to make money (particularly in China), and given the importance placed on Asian values by Asian elites, an understanding of the interaction of culture and politics is essential for an understanding of international relations.

The book includes some excellent tables and various little asides (boxes) that fit well with a textbook-style structure. Most of the chapters are quite short and the book itself is only just over 200 pages (this should help make it attractive to most undergraduates!). It has been extremely well edited. There are some minor criticisms that could be made: the book doesn't contain a conclusion, the size of the font could have been slightly larger, and a glossary or list of acronyms should have been included. 
Overall, however, this will make a fine textbook for courses on IR and East Asia.

Globalisation in the Asian Region comes out of Monash University's Institute for the study of Global Movements, which 'seeks to both describe and understand the causes and consequences of newly emerging patterns in the global movement of people, ideas and capital' (p. ix): a fairly wide ambit. In the preface, Gary Bouma tells us that the editors and contributors have sought to avoid ideology. This statement always amuses me: ideology is what other people do. Perhaps the word polemic would be more appropriate.

The editors provide a sound, but brief, framework and introduction to globalisation in which they utilise Jan Scholte's five definitions of globalisation: internationalisation, liberalisation, universalisation, westernisation or modernisation and, finally, supraterritoriality. It is only the last of these, the editors contend, that is truly new:

[S] upraterritorial phenomena-in the sense of phenomena characterized by trans- world simultaneity and instantaneity (such as the internet and global mass travel)-are a distinctly new feature of human social experience that terminology and concepts derived from older discourses on modernity cannot adequately rep-resent without recourse to the use of new formulations and descriptions. (p. 6)

The approach is not from IR or IPE, but from sociology-or Globology as Bergesen (1982) or Robertson (1992) might call it. While the editors contend, following Scholte, that supraterritoriality is unprecedented, I would have liked to have seen some effort made in the introduction to quantify its extent and novelty: measurement still matters. This is significant because they tell us that: 'all chapters of this book (including this 
introduction) draw on the five definitions of globalization provided by Scholte' (p. 11). It is not true just because Jan says it is!

The introduction provides some general information on globalisation, but the volume would have benefited from a more extensive chapter-length analysis of the impact of globalisation on the region. While Vivienne Wee's chapter on globalisation provides some interesting points, it does not set the scene for the remainder of the more focused studies. The point of departure on globalisation for Wee is post-11 September 2001, rather than post-crisis. And while this may please students sick of the debate about the causes and consequences of 1997 - 98 in Asia, this period remains pivotal to understanding the impact of globalisation and, perhaps most importantly, the perceptions of Asian elites about the position of Asian countries in the global economy. The first two chapters deal with globalisation in a post-9/11 world. Wee considers 'September 11 and its militarized aftermath' concluding that: 'The "new globaliza- tion" is shaped, however, more by security concerns than by economic interests' (p. 25). Unfortunately, insufficient evidence is provided to back up this and some other fairly bold claims: 'a process of market fragmentation is happening with ethnicized markets emerging for ethnicized capital and products' (p. 28) and 'rather than trade, it is now fear that is being globalized' (p. 31). David Wright-Neville con- siders the Southeast Asian experience of terrorism as a global phenomenon, outlining how a region relatively free of 'internecine hatreds' is descending into 'intra-mural' with a 'civilizational dimension' (p. 39). He argues that 'terrorism cannot be defeated' and the 'best that can be hoped for is a strategy that effectively minimizes and manages the terrorist threat. Such a strategy needs to address the deep existential anger generated by the economic 
and cultural anxieties of our time' (p.49). Force is unlikely to be successful on its own.

Vi Meghnad Desai's chapter, 'Globalization and Poverty', could have been more focused on the Asian region. His major point seems to be that:

The nation-state was invented to stop the movement of people ... We have to understand that there is going to be a need to match the free movement of capital with the free movement of labour. There is little reason why people who accept the free movement of capital should not accept the free movement of people. (p. 59)

While this is perhaps an appropriate stance for an academic, I am sure that, if pressed, most politicians and large sections of the populations of the developed world would be able to provide several reasons.

What follows is a series of studies on the impact of globalisation on particular countries. First off the rank is Malaysia. Tham Siew-Yean argues that, despite its reputation as anti-globalisation: 'it would be more accurate to describe Malaysia's approach to globalization as one that sought not "close" but selective integration with the world economy' (pp. 63 -4). He argues for 'FDI friendly policies' (p. 76) and remarks that, since the crisis, 'Malaysia is still dependent on the very same drivers of globalization that spurred its development before the crisis' (p. 78). Robert Rice and Idris Sulaiman provide a 'case study' on the impact of globalisation on the Indonesian economy. While the crisis has made many wary of globalisation, the authors argue that sound management will allow Indonesia to benefit from globalisation.

In the next chapter, Marika Vicziany contends that, 'the current degree of economic and technological integration is small and that more globalization rather than less would be 
to India's benefit' (p. 92). He outlines his considerable concerns about the impact of Hindu nationalism and lists a range of domestic and international constraints on India's global integration. He is particularly critical of the protection- ism of the developed world, especially in agriculture. Despite its lack of globalisation, Vicziany argues that India punches above its economic and technological weight in matters of global politics' (p. 104).

Chris Nyland and Russell Smyth explain Australia's shift from 'multilateralism to imperial preference' outlining the shift away from Labor's multilateral neo-liberal agenda to the Coalition's neo-liberal emphasis on its relationship with the United States. The authors investigate the Australia- US Free Trade Agreement and contend that it is best seen as a part of a 'wedge'-based political strategy that aims to continue neo-liberal globalisation, emphasise the difference between the Australian Labor Party and the Coalition and to accrue the benefits of playing 'deputy' to the United States. This, they suggest, 'will return Australia to a position similar to that which prevailed under the interwar Imperial Preference system' (p. 118). The authors canvass the possibility of the success of this strategy in relation to agricultural trade and getting a 'share of the booty' won by the occupation of Iraq. Notwithstanding the fact that things have not turned out so positively, the article pro-vides an interesting insight into the Coalition's thinking.

The chapter on New Zealand covers the 'movements of people, trade, global trends and the international flow of ideas' (p. 143). In terms of trade, John Ballingall, Phil Briggs and Joanna Smith argue that 'New Zealand has not fully latched on to the globalization 
process' (p. 155). The chapter, however, does not really have an argument beyond the point that: 'it is probably fair to say that the nation as a whole is not sufficiently outward-looking' (p. 161). While this may be a matter of emphasis, what probably cannot be argued is that New Zealand has not embraced neo-liberalism.

For many critics of Japan, the subject of the next chapter, it is an absence of neoliberalism that it is fundamental to Japan's long stagnation. But as Ross Mouer points out, the modern history of Japan is all about its brilliance in integrating and effectively utilising foreign ideas. He argues that: 'The debate concerning the future of Japan is partly about the future of Japan's corporate culture and its social ethos - the need to be internationally transparent in ways that facilitate both a new level of integration into the global economy and the increased movement of people into and out of Japan' (p. 169).

No volume on the Asia-Pacific would be complete without a chapter on the remarkable growth and globalisation of the Chinese economy. Gloria Davies and Russell Smyth argue that the costs of 'the increasing disciplines of international market forces have been "downplayed among the advocates of further globalisation"' (p. 186). They go on to explain that: 'As a kind of ideological lure, "neoliberalism" obscures social inequities in lived everyday experience by readily justifying these as "costs" incurred in the grand project of an ever-expanding global free market' (p. 190). They then go on to assess the problems of China's entry into the World Trade Organisation and other challenges of globalisation such as China's bad debts and growing inequality. The final two chapters provide useful case studies of FDI in China and the movement of people between Hong 
Kong and the mainland. The book, despite Bouma's contention, has its own ideological predispositions. In particular, it is critical of neo-liberal views of globalisation and especially the view that this is the only possible global trajectory. The editors correctly argue that:

Our view, as represented in this introduction and in our design of this book, is that globalization is not inherently good or bad or even singular (that is the same thing for everyone). The manner of its evolution is greatly dependent on the policy alternatives chosen. (p. 9)

The problem for those arguing this case (including me) is the continuing strength of the neo-liberal view among policy makers, especially in the English-speaking world, despite all the evidence from comparative political economy and the varieties of capitalism literature. Despite the criticisms of the editors about neo-liberalism, this is not an antiglobalisation text, as the chapters on Malaysia, Indonesia and India make clear. There have always been multiple facets of globalisation and there will probably always be multiple paths to the future. Success for countries in the region will also probably continue to involve ignoring the dictates of the neo-liberals. That is, of course, a normative, even ideological, position, but it is one that is hope-fully less dogmatic than some!

Some criticisms: a conclusion, once again, might have been a better point of departure for the volume than a case study. And where is that list of acronyms? Finally, is it not possible to make books so that they do not fall apart before one finishes reading them? Nevertheless, despite my criticisms, this is a recommended book for all those interested in the Asia-Pacific and the different ways in which globalisation and its effects can be 
understood.

\section{References}

Bergesen, A. 1982. 'The Emerging Science of the World-system.' International Social Science Journal 34: $23-36$.

Robertson, R. 1992. Globalization. London: Sage. 